\title{
PROFIL SOSIAL BUDAYA MASYARAKAT NELAYAN PERAIRAN LAUT DI INDONESIA
}

\author{
Zahri Nasution dan Tjahjo Tri Hartono")
}

\begin{abstract}
ABSTRAK
Penelitian dengan tujuan mendapatkan profil sosial budaya masyarakat nelayan perairan laut di Indonesia telah dilakukan pada tahun 2003. Lima dimensi kehidupan masyarakat nelayan, yaitu kesehatan masyarakat, ekonomi, hukum adat, politik, dan tingkah laku beserta faktor-faktor penyusunnya, digunakan sebagai indikator yang menggambarkan kondisi sosial budaya masyarakat nelayan. Profil dikemukakan secara kualitatif dan dibahas secara deskriptif. Dari masyarakat nelayan perairan laut di 6 (enam) lokasi penelitian, yaitu Medan, Cirebon, Tegal, Pasuruan, Bone dan Lembata didapat bahwa masyarakat nelayan memiliki karakteristik masyarakat pedesaan dan ada kecenderungan transisi menuju karakteristik masyarakan urban. Karakteristik pedesaan dan perkotaan yang dimaksud mengindikasikan perlunya arahan kebijakan atas pengelolaan sumberdaya berbasis co-management dan pengembangan mata pencaharian alternatif.
\end{abstract}

\begin{abstract}
The profile of socio-culture conditions of coastal fisher societies in Indonesia. By: Zahri Nasution and Tjahjo Tri Hartono

Research with an aim to get the profile of socio-culture of coastal fisher society have been conducted in 2003. Five dimensions which consisting of society, economic, customary law, political, and behaviour along with their compiler factors was described and analized qualitatively in order to generate the common symptons which are found in the communities. The result shows two common characteristics of fisher communities in Indonesia. Some of characteristics reflecting the characteristic of village communities and the others being a characteristic of urban communities. Those characteristics indicate the needs of co-management policies of natural resources and the development of alternative livelihoods.
\end{abstract}

KEYWORDS: socio-culture profile, coastal, fisher society

\section{PENDAHULUAN}

Saat ini disadari bahwa pembangunan masyarakat, baik secara langsung maupun tidak langsung, telah menyebabkan perubahan struktur dan tata nilai masyarakat. Perubahan itu tampak dari adanya "reaksi" yang berbeda-beda dari masyarakat, yang sesungguhnya menginginkan suatu "adaptasi" terhadap keadaan baru yang diakibatkan oleh pembangunan (Susanto, 1984). Perbedaan reaksi tersebut menjadi perhatian para pembuat kebijakan pembangunan di banyak negara, tatkala tata laksana pembangunan yang berbasis pendekatan top-down sesungguhnya tidak berbeda antara satu daerah dengan daerah lain dan antara satu masyarakat dengan masyarakat lainnya. Keragaman tingkat keberhasilan pembangunan tersebut ternyata diakibatkan oleh adanya kemajemukan kondisi sosial budaya masyarakat (Susanto, 1984).
Saat ini, negara-negara maju (Amerika dan Eropa) telah banyak melakukan studi atau penelitian dengan tujuan mengkoleksi data atau informasi mengenai kondisi sosial budaya masyarakat. Pelaksanaan studi seperti ini didasari pada pandangan akan pentingnya data kondisi sosial budaya masyarakat, baik untuk tahap perencanaan, pelaksanaan maupun evaluasi suatu program pembangunan (Cernea, 1988; Masinambouw, 1997). Sementara itu, informasi tentang gambaran atau profil kondisi sosial budaya masyarakat di Indonesia masih belum memadai (Koentjaraningrat, 1988 dalam Masinambouw, 1997).

Penelitian ini bertujuan menghasilkan profil atau informasi tentang kondisi sosial budaya masyarakat nelayan di Indonesia. Kemajemukan sosial budaya yang diperoleh kemudian dianalisis untuk mendapatkan suatu generalisasi gejala sosial budaya atau dengan kata lain, penentuan ciri-ciri umum kondisi sosial budaya masyarakat nelayan yang

\footnotetext{
-) Peneliti pada Pusat Riset Pengolahan Produk dan Sosial Ekonomi Kelautan dan Perikanan
} 
diteliti. Ciri-ciri umum yang diperoleh diharapkan berfungsi sebagai acuan umum dan bahan rekomendasi untuk penajaman dan penyempurnaan arah dan strategi pelaksanaan program pembangunan masyarakat nelayan di Indonesia.

\section{METODE}

\section{Pendekatan dan Lingkup Penelitian}

Penelitian bersifat studi kasus. Sebagai studi kasus, kesimpulan yang dihasilkan terbatas pada komunitas yang diteliti. Untuk lingkup kehidupan sosial yang lebih luas, kesimpulan tersebut hanya berlaku sebagai proposisi hipotetis.

Penelitian menggunakan pendekatan sosioantropologi. Pendekatan ini memadukan pendekatan sosiologi dan antropologi, dengan tujuan agar hasil penelitian dapat menggambarkan gejala masyarakat yang kompleks berikut kebudayaannya, sebagai suatu kesatuan yang saling mempengaruhi kehidupan suatu masyarakat secara menyeluruh (holistik). Tergambarnya sistem dan tata nilai kehidupan masyarakat dan individu-individu anggota masyarakat serta kekuasaan dan wewenang yang terjadi di masyarakat nelayan pada akhirnya akan berperan penting sebagai bahan pertimbangan perencanaan dan pelaksanaan program pembangunan di masyarakat nelayan.

Penelitian menggunakan lima dimensi sosial budaya masyarakat meliputi dimensi kesehatan masyarakat, ekonomi, hukum adat, politik, dan tingkah laku (Nasution, et al., 2004). Dimensi-dimensi tersebut difungsikan sebagai aspek-aspek kehidupan masyarakat. Didalam penggunaannya, setiap dimensi disusun dari beberapa faktor penjelas yang memiliki peran yaitu menggambarkan kondisi sosial budaya masyarakat nelayan.

\section{Lokasi Penelitian}

Lokasi penelitian ditetapkan dengan sengaja (purposive). Di tingkat propinsi, penetapan lokasi didasarkan pada perbedaan wilayah penangkapan. Propinsi Sumatera Utara ditetapkan sebagai contoh masyarakat nelayan di perairan laut wilayah Pantai Timur Sumatera, kemudian tiga propinsi yaitu Propinsi Jawa Barat, Jawa Tengah dan Jawa Timur ditetapkan sebagai contoh masyarakat nelayan di perairan laut wilayah Pantai Utara Jawa. Propinsi Sulawesi Selatan dan Nusa Tenggara Timur ditetapkan sebagai contoh masyarakat nelayan di perairan laut wilayah Timur Indonesia.

Lokasi penelitian di tingkat kabupaten/kota adalah lokasi-lokasi dengan potensi perikanan tangkap yang cukup signifikan bagi propinsi terpilih. Informasi tersebut diperoleh melalui cara konsultasi dan diskusi terhadap Dinas Kelautan dan Perikanan Propinsi.

\section{Unit Analisis}

Unit analisis penelitian adalah masyarakat nelayan suatu desa atau komunitas di kabupaten terpilih. Namun demikian, secara kesatuan, unit-unit analisis tersebut diasumsikan dapat menggambarkan suatu kesatuan kondisi sosial budaya dari berbagai masyarakat nelayan di Indonesia.

\section{Metode Pengumpulan Data}

Data yang dikumpulkan adalah informasi partisipatif, dengan demikian pengumpulan data dilakukan dengan teknik Participatory Rural Appraisal (PRA) melalui wawancara dan observasi. Wawancara dengan informan (utama dan kunci) dilakukan berdasarkan panduan topik pertanyaan, yang mencakup lima aspek atau dimensi kondisi sosial budaya masyarakat nelayan. Validitas panduan pertanyaan yang digunakan tersebut ditentukan berdasarkan validitas isi (Danim, 2003).

Informan pertama atau informan kunci (key person) adalah tokoh masyarakat yang ditetapkan secara purposif (sengaja) melalui informasi yang diperoleh dari Dinas Perikanan dan Kelautan terpilih. Informan selanjutnya, baik tokoh masyarakat dan atau nelayan didapat dengan menggunakan teknik snowball (Wahyono et al., 2001) informan yang diinginkan peneliti adalah nelayan yang melaksanakan usaha penangkapan ikan minimal berpengalaman 10 tahun dan menetap di desa lokasi penelitian selama minimal 10 tahun. Nilai 10 tahun dianggap telah cukup waktu untuk memahami usaha yang dilaksanakannya dan juga telah memahami keadaan sosial budaya masyarakat mereka secara baik dan menyeluruh. Informan kunci berupa tokoh masyarakat juga ditetapkan secara sengaja guna mendapatkan informasi yang sama.

Informan nelayan diklasifikasi menurut statusnya yaitu juragan darat, juragan laut dan pendega/ABK (Anak Buah Kapal). Juragan darat adalah mereka yang memiliki kapal, alat penangkap ikan, biaya operasional ke laut tetapi tidak turut serta melaksanakan penangkapan ikan kelaut. Juragan laut adalah mereka yang memiliki kapal, alat penangkap ikan, biaya operasional ke laut dan turut serta melaksanakan penangkapan ikan ke laut. Kemudian, pendega atau ABK adalah mereka yang melaksanakan operasional penangkapan ikan dengan berbagai tingkatannya, dan nelayan ini dijadikan responden dalam penelitian ini.

Observasi atau pengamatan dilakukan terhadap fakta-fakta sosial yang mencerminkan kondisi sosial 
budaya masyarakat nelayan. Pengamatan dipusatkan pada pengenalan serta pemahaman tentang kondisi perumahan dan lingkungan perumahan atau kampung nelayan pada setiap wilayah penelitian. Pengamatan juga dilakukan terhadap aktivitas kenelayanan seharihari yang dilakukan oleh masyarakat nelayan.

\section{Metode Analisis Data}

Data yang terkumpul diolah dalam pernyataanpernyataan deskriptif. Hasil olahan selanjutnya dikaji dengan konsep-konsep dan teori-teori sosiologi dan antropologi. Fokus kajian adalah perspektif atau cara pandang informan tentang masyarakat, sistem dalam kehidupan masyarakat, individu-individu anggota masyarakat serta kekuasaan dan wewenang (Berry, 2003; Nasution et al., 2004).

\section{HASIL DAN BAHASAN}

\section{Profil Sosial Budaya Masyarakat Nelayan}

\section{Dimensi kesehatan masyarakat}

Penggalian informasi tentang pandangan, perilaku dan tindakan sehari-hari masyarakat nelayan yang terkait dengan kesehatan dalam rangka peningkatan kualitas sumberdaya manusia di sektor kelautan dan perikanan (nelayan). Oleh karena itu, informasi yang dikumpulkan adalah pandangan masyarakat nelayan tentang hidup sehat, sakit, cara mengatasi penyakit, pantangan atau kebiasaan makan dan sanitasi perumahan dan lingkungan.

Hidup sehat bagi masyarakat nelayan memiliki pengertian sebagai suatu keadaan di mana mereka tidak sakit dan dapat bekerja untuk melaksanakan kegiatan penangkapan ikan. Hidup sehat juga diartikan oleh mereka sebagai hidup tanpa kekurangan sesuatu apapun dalam kaitannya dengan pemenuhan kebutuhan dasar keluarga (sandang, pangan dan papan).

Berdasarkan pendapatnya tentang sakit masyarakat nelayan pada prinsipnya terbagi menjadi dua kelompok. Kelompok pertama berpendapat bahwa sakit adalah kondisi kesehatan yang membuat mereka tidak memungkinkan untuk bekerja (ke laut). Sementara untuk kelompok kedua, sakit merupakan kondisi kesehatan yang membuat mereka tidak dapat lagi "berdiri", atau tidak sanggup lagi untuk melakukan aktivitas sehari-hari di dalam rumah. Jadi, selama masih bisa "berdiri" dan karenanya mereka masih dapat pergi ke laut untuk bekerja, maka kondisi kesehatan seperti itu belum digolongkan sebagai sakit. Anggapan dari kelompok inilah yang secara umum, menurut para nelayan dari kelompok pertama, sebagai penyebab terjadinya kecelakaan di laut. Kelompok nelayan ini menyatakan bahwa kecelakaan laut akibat buruknya cuaca jarang terjadi karena nelayan cukup berpengalaman dalam menentukan layak tidaknya cuaca bagi mereka untuk pergi melaut.

Dalam hal mengatasi penyakit, informasi didapat dari masyarakat tentang pihak yang didatangi untuk dimintai pengobatan (dokter atau dukun) oleh masyarakat serta jenis obat apa (tradisional atau modern) yang dikonsumsi oleh masyarakat. Pada saat ini masyarakat nelayan di wilayah Medan dan seluruh lokasi di Pulau Jawa sebagian besar menyatakan bahwa dukun diperlukan hanya sebagai alternatif pengobatan. Mendatangi dukun hanya dilakukan manakala penyakit yang diderita sesuai dengan keyakinan masyarakat nelayan tidak dapat diobati oleh pengobatan medis, seperti dokter atau bidan. Sementara itu, bagi masyarakat nelayan di wilayah Kabupaten Lembata dukun masih menjadi tujuan utama tatkala mereka sakit. Kebiasaan ini, disamping didasari oleh kepercayaan (sugesti) masyarakat atas kemampuan dukun dalam mengobati penyakit, juga didasari pada pertimbangan biaya pengobatan yang relatif lebih murah dibandingkan dengan dokter atau tenaga medis lainnya (dokter atau mantri). Alasan yang berbeda dikemukakan oleh masyarakat nelayan di wilayah Bone. Miereka masih tetap menggunakan jasa dukun sebagai tujuan utama untuk upaya pengobatan, namun kebiasaan ini lebih didasarkan pada masalah keengganan mereka untuk pergi ke dokter atau Puskesmas, dikarenakan jarak yang jauh dari tempat tinggal mereka $(10 \mathrm{~km})$ serta dalam kondisi rusak

Pada hampir seluruh wilayah, masyarakat nelayan mengemukakan bahwa penggunaan obat-obatan tradisional saat ini cenderung meningkat. Mereka lebih memprioritaskan penggunaan obat-obatan tradisional terlebih dahulu daripada obat-obatan buatan pabrik atau yang diresepkan dokter. Hal ini dilakukan nelayan berdasarkan pertimbangan harga obat tradisional yang lebih murah, disamping praktis digunakan pada saat melaksanakan kegiatan penangkapan ikan (kemasannya lebih tahan air). Perbedaan kecil ditemukan pada masyarakat nelayan di desa contoh di Kota Medan. Nelayan di wilayah ini menganggap bahwa obat-obatan tradisional dan obat buatan pabrik sama pentingnya tergantung penyakit yang diderita.

Jika terdapat sesuatu pantangan atau hal yang tabu maka nelayan pada semua wilayah penelitian mengemukakan bahwa mereka akan mematuhinya sebagai budaya. Sejalan dengan hal ini adalah pendapat Foster \& Anderson (1986). Mereka menyatakan bahwa pada anggota tiap masyarakat, makanan dibentuk secara budaya, yang berarti 
diperlukan pengesahan budaya dan keaslian untuk sesuatu yang akan dimakan. Makanan yang sebetulnya bergizi baik menjadi tidak boleh dimakan dikarenakan adanya pantangan agama, takhyul, kepercayaan tentang kesehatan, dan suatu peristiwa yang kebetulan dalam sejarah. Makanan ini selanjutnya dikategorikan oleh masyarakat yang bersangkutan sebagai bukan makanan. Pada masyarakat nelayan yang diteliti, pantangan makan atau makanan yang dilarang hanyalah jenis-jenis makanan yang dilarang oleh ajaran agama yang mereka anut (Islam).

Kemudian masyarakat nelayan pada umumnya juga menyatakan bahwa kondisi di dalam dan di sekitar rumah harus bersih agar mereka dapat hidup sehat. Namun demikian keberadaan dan pemilikian fasilitas Mandi Cuci Kakus (MCK) yang memenuhi standar kesehatan baru dijumpai di masyarakat nelayan Cirebon dan Tegal. Keberadaan fasilitas itu pun ternyata belum mengubah kebiasaan mereka untuk tetap memanfaatkan sungai dan pantai sebagai tempat fasilitas MCK. Sedangkan masyarakat nelayan di wilayah Bone dan Lembata sebagian besar belum memiliki fasilitas MCK keluarga.

\section{Dimensi ekonomi}

Kehidupan ekonomi dalam kaitannya dengan sosial budaya masyarakat nelayan adalah penggalian informasi mengenai: (1) Pengaruh sistem kemasyarakatan terhadap aktivitas kehidupan ekonomi; (2) Cara berpikir, pandangan dan sikap warga masyarakat terhadap aktivitas kehidupan ekonominya; (3) Sikap hidup dari warga masyarakat terhadap kekuatan, proses, dan hukum-hukum ekonomi yang berlaku dalam aktivitas kehidupan ekonominya; (4) Sikap warga masyarakat terhadap kerja, kekayaan dan sistem gotong-royong. Informasi akan hal-hal yang dimaksud diharapkan dapat menjelaskan bagaimana dan mengapa masyarakat nelayan membentuk dan menjalani kehidupan perekonomiannya.

Khusus di Kabupaten Lembata terdapat pengaturan secara adat yang berlaku dalam kegiatan penangkapan ikan paus. Aturan adat tersebut mulai dari pembuatan perahu, persiapan, pelaksanaan penangkapan dan pembagian hasil tangkapan. Aturan adat ini telah berlaku secara turun temurun dalam masyarakat nelayan di wilayah ini. Sementara untuk wilayah penelitian lainnya saat ini tidak ada aturan ataupun norma yang bersumber dari masyarakat nelayan setempat, di mana aturan tersebut berpengaruh terhadap aktivitas kehidupan ekonomi masyarakat itu sendiri. Aturan hanya ada melalui saluran formal yang bersumber dari pemerintah.
Pedagang memegang peran yang besar pada kegiatan ekonomi nelayan. Kondisi ini dijumpai di seluruh masyarakat nelayan tangkap di Pulau Jawa yang diteliti. Tampak sekali pada masyarakat nelayan di wilayah-wilayah tersebut telah terbentuk hubungan patron klien antara pedagang (patron) dan nelayan (klien). Pada hubungan ini, sesungguhnya nelayan berada pada posisi dirugikan karena ikan hasil tangkapan harus dijual kepada pedagang dengan harga yang ditetapkan secara sepihak oleh pedagang.

Berbeda dengan fakta yang ditemukan di masyarakat nelayan di lokasi penelitian di Pulau Jawa, di Medan pedagang tidak banyak berperan terhadap aktivitas nelayan kecil seperti nelayan pukat. Hal ini disebabkan pedagang memiliki pengalaman buruk, yaitu seringkali mendapat kesulitan (gangguan keamanan) dalam berhubungan dengan nelayan kecil seperti nelayan pukat. Sementara di wilayah Kabupaten Lembata, pedagang bahkan sama sekali belum memiliki peranan, baik pada kegiatan penangkapan ikan ataupun pemenuhan kebutuhan hidup sehari-hari nelayan.

Lembaga keuangan formal dalam hubungannya dengan pengembangan ekonomi masyarakat nelayan, sebagai contoh untuk penyediaan kredit usaha perikanan, di semua wilayah penelitian belum berperanan. Peranan lembaga keuangan (bank) yang dijumpai di wilayah Kota Medan sebatas menyediakan fasilitas kredit perumahan nelayan yang dibangun seperti layaknya program perumahan umumnya. Di wilayah Cirebon dan Tegal, peranan lembaga keuangan lebih dirasakan oleh pedagang. Pedagang dirasakan lebih memahami aturan-aturan atau prosedural yang dikeluarkan dan disyaratian oleh lembaga keuangan untuk dipenuhi oleh nasabahnya.

Diversifikasi mata pencaharian sebagai salah satu cara nelayan dalam menyikapi kondisi perekonomiannya jarang dijumpai pada individu informan dalam kategori nelayan kecil atau nelayan yang berstatus Anak Buah Kapal di masyarakat nelayan (laut) di Pulau Jawa (Cirebon, Tegai dan Pasuruan). Mata pencaharian alternatif yang ada, lebih banyak dilakukan oleh anggota keluarga seperti istri dan anak. Mereka beiprofesi sebagai pedagang ikan di pasar atau tenaga kerja di tempat pengolahan ikan. Perlu diberi perhatian dalam hal ini adalah pada masyarakat nelayan di Medan dan Pasuruan. Di kedua wilayah tersebut belum dijumpai masyarakat nelayan yang melakukan aktivitas ekonomi di luar bidang perikanan.

Masyarakat nelayan yang diteliti juga memiliki pemahaman bahwa dalam aktivitas kehidupan ekonominya berlaku kekuatan, proses dan hukumhukum ekonomi. Hal ini terbukti dari kesadaran mereka tentang adanya pengaruh berupa peningkatan 
hasil tangkapan melalui peningkatan kemampuan alat tangkap dan perahu atau kapal yang dimilikinya. Disamping itu kesadaran akan hukum-hukum ekonomi yang terjadi pada usaha penangkapan ikan disikapi juga sebagai penambahan armada. Semakin banyak alat tangkap yang digunakan diyakini memperbesar kemungkinan mendapatkan hasil tangkapan yang lebih banyak.

Namun demikian kesadaran akan hal tersebut tidak diimbangi oleh tersedianya kemudahan bagi para nelayan (kecuali di Pasuruan) untuk mendapatkan pinjaman dari lembaga keuangan formal atau pemerintah. Dalam hal ini mereka akhirnya terpaksa berusaha memelihara peralatan penangkapan mereka semaksimal mungkin sehingga dapat digunakan dalam jangka waktu lebih lama. Cara lain adalah dengan meminjam pada pedagang ikan, cara yang membuat kembali terjalinnya ikatan patron-klien.

Secara umum, menurut nelayan yang dimaksud dengan kerja adalah suatu keperluan (kegiatan) untuk dapat menghidupi keluarga. Bagi masyarakat nelayan di wilayah Lembata ditambah pula sebagai tugas suci, hal ini terutama dalam usaha penangkapan ikan paus.

Terkait dengan pandangan masyarakat tentang kekayaan, disebutkan oleh mereka bahwa kekayaan adalah rezeki dari Yang Maha Kuasa tetapi dalam mendapatkannya diperlukan usaha. Indikator kekayaan secara umum adalah bila seorang anggota masyarakat nelayan mampu memiliki rumah bagus, alat tangkap ikan yang banyak dan sepeda motor. $\mathrm{Hal}$ ini yang membuat pedagang atau juragan, yang umumnya memiliki harta benda seperti yang disebutkan, menjadi profesi yang dicita-citakan oleh nelayan. Namun demikian, dijumpai pula nelayan yang berpandangan bahwa indikator kekayaan adalah kecukupan pangan, sandang dan perumahan.

Kemudian menurut sebagian besar nelayan, sistem gotong royong adalah kerja sama-sama menyelesaikan pekerjaan yang besar. Dinyatakan pula oleh mereka bahwa sistem ini baik terutama dalam melaksanakan pekerjaan padat karya seperti pembuatan jalan RW di lingkungan perumahan. Namun demikian pada saat ini diketahui bahwa pada sebagian besar masyarakat nelayan, terutama nelayan berusia muda, terlihat ada kecenderungan berkurangnya penggunaan sistem gotong royong sejak tahun 1998 kecuali di wilayah Pasuruan. Bahkan di Cirebon, masyarakat nelayan menyatakan bahwa mereka tidak mempunyai waktu lagi untuk melakukan aktivitas gotong royong. Sementara itu, sistem gotong royong yang masih berlaku dalam kegiatan penangkapan ikan paus yang dilakukan oleh masyarakat nelayan di desa Lamalera, Kabupaten Lembata tampaknya sangat terkait erat dengan tingginya tingkat ketaatan mereka terhadap pemuka agama setempat.

\section{Dimensi hukum}

Penggalian informasi dimensi hukum didapat dari pandangan masyarakat nelayan tentang beberapa hal yang pada intinya mencakup aktivitas-aktivitas yang berfungsi di lapangan sebagai pengendalian sosial (social control) dan diuraikan sebagai berikut:

Terkait dengan pengaturan di dalam kegiatan penangkapan ikan, di masyarakat Lembata, NTT terdapat tradisi penangkapan ikan paus dalam bentuk hukum adat yang mengatur/melarang penggunaan alat-alat modern (misalnya perahu bermotor atau bom). Oleh karena itu, hingga saat ini kegiatan penangkapan ikan paus tetap berlangsung secara tradisional menggunakan tombak (tempuling) dan menggunakan perahu tanpa motor.

Tidak ditemukan hukum adat yang masih berlaku atau pernah ada dalam kegiatan penangkapan ikan pada masyarakat yang diteliti di wilayah lainnya. Pengaturan tentang penangkapan ikan yang diketahui masyarakat adalah pengaturan positif, berasal dari pemerintah seperti larangan penangkapan ikan menggunakan bom dan listrik. Pengaturan tentang penyelesaian konflik yang diatur secara hukum adat juga tidak ada kecuali di wilayah Kabupaten Lembata dan Bone. Penyelesaian konflik juga sebatas dalam bentuk musyawarah dan jika tidak dapat diselesaikan dengan cara ini langsung diserahkan kepada pihak yang berwajib.

\section{Dimensi politik}

Kajian atas dimensi politik bertujuan untuk melihat pola kekuasaan, wewenang dan kepemimpinan yang ada pada masyarakat nelayan. Pada akhirnya, pola yang didapat akan menentukan tingkat keberdayaan masyarakat nelayan yang bersangkutan itu sendiri.

Pada sebagian besar masyarakat nelayan yang diteliti, ditemukan anggapan bahwa semua partai politik adalah sama. Mereka tidak mengetahui bagaimana hubungan antar partai politik tersebut dalam hubungannya dengan sistem pemerintahan yang ada di wilayah mereka. Mereka juga beranggapan bahwa bukan suatu hal yang penting untuk mengetahui kekuatan partai politik lokal ataupun nasional. Hal yang penting bagi mereka adalah siapapun yang bertugas di pemerintahan diharapkan dapat mensejahterakan masyarakat nelayan. Hal ini tercermin dari pendapat mereka yang menyatakan bahwa masyarakat nelayan menerima dengan baik program yang disampaikan, baik oleh pemerintah ataupun LSM, dengan catatan program 
tersebut bertujuan meningkatkan kesejahteraan mereka.

Di sebagian besar wilayah penelitian belum tampak organisasi masyarakat nelayan (Himpunan Nelayan Seluruh Indonesia - HNSI) yang dapat berfungsi dengan baik. Pandangan ini muncul dari pendapat masyarakat nelayan, yang menyatakan bahwa mereka belum banyak memperoleh bantuan terhadap kegiatan ekonomi mereka dari organisasi tersebut. Bantuan yang banyak mereka ungkap terutama terkait dengan pengadaan alat tangkap. Berfungsinya HNSI hanya terlihat di masyarakat nelayan di Medan. Organisasi nelayan di wilayah ini telah berhasil memperjuangkan tersedianya kompleks perumahan bagi masyarakat nelayan. Pembangunan perumahan tersebut dilakukan pemerintah untuk masyarakat nelayan dalam bentuk kredit di suatu lembaga keuangan formal (bank). Perumahan tersebut dilengkapi dengan fasilitas penjemuran jaring bagi nelayan dan fasilitas lainnya seperti ruang pertemuan bagi nelayan (pendopo /rumah terbuka), toko peralatan penangkapan ikan dan kebutuhan pokok sehari-hari bagi warga setempat disamping sarana transportasi yang cukup memadai berupa jalan yang beraspal.

Kepemimpinan yang baik menurut nelayan adalah cara seseorang atau pimpinan masyarakat yang di dalam memimpin masyarakatnya disertai dengan menunjukkan teladan yang baik. Sedangkan latar belakang sosial budaya kekuatan politik dalam sistem pemerintahan di tingkat kecamatan atau desa dimana responden berada dipengaruhi oleh latar belakang agama (ajaran Islam dan Kristen - khusus untuk wilayah Kabupaten Lembata) serta budaya setempat.

\section{Dimensi tingkah laku}

Dimensi ini merupakan kajian sosial budaya dilihat dari perspektif individu dan bukan sebagai anggota masyarakat yang terikat oleh norma-norma yang dibentuk oleh masyarakat dimana si individu itu hidup dan tinggal. Hal ini perlu didalami semenjak ada beberapa faktor kepribadian seseorang yang tidak tergantung pada perannya didalam suatu masyarakat. Untuk itu, didalam dimensi ini kajian difokuskan pada penggalian informasi yang terkait dengan pendapat individu dalam masyarakat tentang: (1) azas-azas kehidupan dan (2) perilaku dan tindakan. Pengetahuan tentang kedua hal tersebut merupakan informasi yang esensial di dalam arahan kebijakan tentang metode pendampingan di lingkup program atau kegiatan pembangunan berbasis pemberdayaan masyarakat.

Pada seluruh wilayah penelitian ditemukan bahwa pedoman utama responden dalam menjalani kehidupan adalah ajaran agama serta budaya setempat. Kemudian, tertangkap pula ungkapan sebagian besar masyarakat nelayan jika mereka akan menyambut baik inisiatif pengaturan sosial ekonomi dari pemerintah atau LSM, asalkan bertujuan membantu atau meningkatkan kesejahteraan mereka.

Sebagian besar masyarakat nelayan di seluruh wilayah penelitian juga menyatakan bahwa secara umum perilaku dan tindakan masyarakat adalah baik. Sejauh ini tidak pernah terjadi penyimpangan perilaku dan tindakan berarti dalam kehidupan sehari-hari masyarakat nelayan. Kebiasaan minum-minuman keras di masyarakat nelayan hanya dianggap sebagai kegiatan dengan latar belakang mencari hiburan saja. Namun demikian, terdapat pandangan dengan nada yang cukup berbeda, baik dari informan masyarakat nelayan maupun tokoh masyarakat, yaitu masih perlunya penyadaran bagaimana seharusnya hidup bermasyarakat pada masyarakat nelayan terutama generasi mudanya.

Informasi-informasi tersebut di atas dapat dijadikan indikasi bahwa di masyarakat nelayan telah terjadi "pemberontakan" atas nilai-nilai atau norma-norma yang berlaku selama ini. Pertentangan tersebut tampak dari pernyataan yang berbeda arah antara kelompok anggota masyarakat yang tua dengan generasi sesudahnya. Perbedaan ini juga merupakan akibat dari adanya difusi kebudayaan dari luar daerah, yang diperoleh dari kemajuan sarana komunikasi dan informasi pada saat ini (misal: adanya siaran televisi dipraduga turut berperan didalam meningkatkan konsumerisme anak-anak nelayan).

\section{Keragaan Sosial Budaya dan \\ Pemberdayaan Masyarakat Nelayan}

Berdasarkan uraian tentang pandangan atas berbagai hal serta kehidupan masyarakat di dimensidimensi yang dianalisis, maka dapat disimpulkan bahwa pada beberapa dimensi atau kondisi sosial budaya yang dikaitkan dengan upaya pemberdayaan masyarakat nelayan laut di Indonesia, tampaknya masih memiliki ciri-ciri umum masyarakat pedesaan. Namun demikian, sebagian kondisi sosial budaya juga telah terjadi proses transisi dari masyarakat yang berkarakter masyarakat pedesaan menjadi masyarakat dengan karakter masyarakat urban (perkotaan). Karakter masyarakat pedesaan di antaranya adalah tingkat konflik dan persaingan yang tinggi, kegiatan bekerja merupakan syarat penting untuk dapat bertahan hidup, masih kentalnya sistem tolong menolong dan jiwa gotong-royong serta masih berjalannya sistem musyawarah yang diteladani oleh tokoh-tokoh masyarakat. Sebaliknya, masyarak $a_{i}$ perkotaan pada umumnya tidak lagi memiliki karakter masyarakat pedesaan sebagaimana yang dimaksud. 
Adapun ciri-ciri umum yang didapat dari masyarakat nelayan tersebut dapat diuraikan sebagai berikut:

Pada dimensi kesehatan, budaya hidup sehat belum tercipta dalam kehidupan sosial budaya masyarakat nelayan. Dalam hal ini, mereka baru sebatas mencapai taraf memahami aspek-aspek yang membentuk budaya hidup sehat. Beberapa hal yang dinyatakan dan merupakan suatu pandangan belumlah diimplementasikan dalam kehidupan sehari-hari oleh sebagian besar masyarakat. Sebagai contoh, pentingnya hidup sehat tidak diimbangi dengan pengobatan yang menyeluruh dan baik, meskipun di beberapa lokasi disebabkan pula oleh kendala biaya dan ketiadaan fasilitas yang terkait. Sanitasi rumah dan lingkungan juga merupakan cerminan kondisi sosial budaya masyarakat tersebut. Sementara, terbentuknya budaya hidup sehat dalam kehidupan masyarakat akan mendukung upaya mengarahkan masyarakat nelayan menjadi sumberdaya manusia yang berkualitas.

Pada dimensi ekonomi, kehidupan masyarakat nelayan di dalam memenuhi kebutuhan hidupnya masih sangat dicirikan oleh aktivitas ekonomi dengan teknologi (alat tangkap) sederhana dan minimnya ketersediaan mata pencaharian alternatif. Disamping itu, kelembagaan ekonomi dan aturan-aturan ekonomi yang mampu dipahami juga belum dijalankan dan cenderung belum mengarah pada efisiensi kegiatan ekonomi (penangkapan ikan) serta pemerataan distribusi hasilnya. Masih kuatnya ikatan patron-klien dan belum menyentuhnya saluran atau lembaga keuangan formal merupakan penyebab utama bentuk kehidupan ekonomi masyarakat nelayan pada saat ini. Lebih lanjut, tidak ditemukannya ikatan patronklien di beberapa masyarakat, lebih mencirikan masyarakat bersangkutan masih belum mencapai tingkat budaya industri yang kuat (seperti di Medan) atau bahkan belum memiliki budaya industri (seperti di Lembata). Dengan demikian karakter masyarakat pedesaan dalam hal ini masih sangat kental sebagai ciri sosial budaya masyarakat nelayan.

Hasil penggalian kondisi ekonomi dari segi gotong royong dan kekayaan juga mendapatkan suatu ciri umum masyarakat nelayan yang diteliti. Dari sisi pandangan dan kebiasaan melakukan kegiatan gotong royong, tampak bahwa masyarakat nelayan sedang mengalami transisi dari masyarakat pedesaan menuju masyarakat urban. Sedangkan pandangan tentang kekayaan menunjukkan ciri umum masyarakat pedesaan di Indonesia, bahwa orang yang bisa bekerja keras dan akhirnya berhasil seminimal mungkin mendapat bantuan dari orang lain sangat dinilai tinggi dalam masyarakat (Koentjaraningrat, 1964).

Pengkajian dimensi hukum juga menunjukkan bahwa secara umum sedang terjadi transisi sosial budaya masyarakat nelayan, dari masyarakat pedesaan menjadi masyarakat urban. Pada umumnya di masyarakat pedesaan, aturan-aturan dalam bentuk hukum adat masih ada dan melekat dalam kehidupan sehari-hari masyarakat, sesuatu yang saat ini sudah tidak lagi dijumpai di masyarakat nelayan kecuali di Lembata, NTT. Sementara melekatnya karakter masyarakat pedesaan tampak dari masih tingginya konflik potensial antar masyarakat nelayan yang menggunakan alat tangkap yang berbeda. Pada masyarakat pedesaan, konflik dan persaingan seringkali muncul saat masyarakat dihadapkan pada perebutan sumberdaya.

Kajian atas dimensi politik, mendapatkan bahwa penanganan konflik yang telah melibatkan pihak luar juga merupakan ciri dari suatu masyarakat yang sedang mengalami transisi sosial budaya. Masuknya pihak luar ke dalam penyelesaian konflik dan terkadang menentukan kehidupan masyarakat secara umum menunjukkan ciri lemahnya akses dan kepedulian masyarakat nelayan terhadap upaya mendapatkan "kekuasaan" dalam mengelola kehidupannya sendiri. Kondisi ini juga menunjukkan tidak adanya kekuatan atau tokoh-tokoh yang sanggup mengarahkan masyarakat untuk berdaya serta di sisi lain juga mendukung kecenderungan telah lemahnya sistem gotong royong pada saat ini di masyarakat nelayan.

\section{KESIMPULAN DAN SARAN}

Hasil kajian menunjukkan bahwa masyarakat nelayan masih memiliki karakter masyarakat pedesaan. Namun demikian, telah tampak pula adanya transisi sosial budaya dari masyarakat pedesaan menuju masyarakat urban.

Menyikapi karakter sosial budaya masyarakat nelayan yang mencirikan suatu masyarakat pedesaan, maka diperlukan arahan kebijakan yang mampu menggerakkan kearifan tradisional masyarakat nelayan yang difasilitasi oleh pemerintah. Sebagai contoh adalah program pengelolaan sumberdaya kelautan dan perikanan yang berdasar pada konsep co-management. Masyarakat pedesaan pada dasarnya merupakan masyarakat yang sanggup bekerja keras, namun untuk itu diperlukan pendampingan dalam perbaikan cara-cara bekerja agar hasil yang diperoleh secara ekonomis efisien. Konsep pembangunan ini juga tidak mengabaikan sistem masyarakat yang secara positif mampu mendukung keberhasilan program pembangunan berbasis pemberdayaan masyarakat.

Hasil yang mencirikan suatu proses transisi dari masyarakat pedesaan menuju masyarakat urban perlu disikapi dengan arahan kebijakan yang mampu 